\title{
BENEFICIAL PROPERTIES OF PROBIOTIC YEAST
}

\section{Saccharomyces boulardii}

\author{
Zorica M. Tomičić ${ }^{\star}$, Radmilo R. Čolović ${ }^{1}$, Ivana S. Čabarkapa ${ }^{1}$, Đuro M. Vukmirović ${ }^{1}$, Olivera M. \\ Đuragić ${ }^{1}$, Ružica M. Tomičić ${ }^{2}$ \\ ${ }^{1}$ Institute of Food Technology, University of Novi Sad, Bulevar cara Lazara 1, 21000 Novi Sad, Serbia \\ ${ }^{2}$ Faculty of Technology, University of Novi Sad, Bulevar cara Lazara 1, 21000 Novi Sad, Serbia
}

*Corresponding author:
E-mail address:zorica.tomicic@fins.uns.ac.rs

\begin{abstract}
Saccharomyces boulardii is unique probiotic and biotherapeutic yeast, known to survive in gastric acidity and it is not adversely affected or inhibited by antibiotics or does not alter or adversely affect the normal microbiota. S. boulardii has been utilized worldwide as a probiotic supplement to support gastrointestinal health. The multiple mechanisms of action of $S$. boulardii and its properties may explain its efficacy and beneficial effects in acute and chronic gastrointestinal diseases that have been confirmed by clinical trials. Caution should be taken in patients with risk factors for adverse events. Its potential application in various dairy foods could offer an alternative probiotic product to people suffering from antibiotic-associated diarrhea. This review discusses the evidence for efficacy and safety of $S$. boulardii as a probiotic for the prevention and therapy of gastrointestinal disorders in humans.
\end{abstract}

Key words: Saccharomyces boulardii, efficacy, safety, probiotic

\section{INTRODUCTION}

\section{Saccharomyces boulardii as a probiotic yeast}

"Probiotics" were first conceptualized at the start of the 20th century by Elie Metchnikoff's discovery of the immunological benefit of lactic acid bacteria in fermented milk. Today, lactobacilli and bifidobacteria are among the most important and widely consumed probiotics (Table 1). Species from other bacterial genera such as Escherichia, Bacillus and Enterococcus have also been used, but there are concerns surrounding the safety of such probiotics as these genera contain opportunistic pathogenic species, particularly Enterococcus (FAO/WHO, 2002). Few non-bacterial microorganisms such as

yeasts, Saccharomyces boulardii and some Saccharomyces cerevisiae strains, are also studied or commercialized as probiotics (Holzapfel et al., 2001). It is important to mention that for a microorganism to be considered probiotic, it must survive passage through the stomach and maintain its viability and metabolic activity in the intestine (van der $\mathrm{Aa}$ Kühle et al., 2005). Native inhabitants of the human or animal gastrointestinal tract, such as lactobacilli and bifidobacteria, are considered to be probiotic, but often display low stress tolerance, which reduces their viability in probiotic applications. 
Table 1. Microorganisms considered as probiotics (Holzapfel et al., 2001)

\begin{tabular}{|c|c|c|c|}
\hline Lactobacillus species & $\begin{array}{l}\text { Bifidobacterium } \\
\text { species }\end{array}$ & $\begin{array}{l}\text { Other lactic acid } \\
\text { bacteria }\end{array}$ & $\begin{array}{l}\text { Non-lactic acid } \\
\text { bacteria }\end{array}$ \\
\hline $\begin{array}{l}\text { L. acidophylus } \\
\text { L. amylovorus } \\
\text { L. casei } \\
\text { L. crispatus } \\
\text { L. delbrueckii subsp. } \\
\text { bulgaricus } \\
\text { L. gallinarum* } \\
\text { L. gasseri } \\
\text { L. johnsonii } \\
\text { L. paracasei } \\
\text { L. plantarum } \\
\text { L. reuteri } \\
\text { L. rhamnosus }\end{array}$ & $\begin{array}{l}\text { B. adolescentis } \\
\text { B. animalis } \\
\text { B. bifidum } \\
\text { B. breve } \\
\text { B. infantis } \\
\text { B. lactis } \\
\text { B. longum }\end{array}$ & $\begin{array}{l}\text { Enterococcus faecalis* } \\
\text { Enterococcus faecium } \\
\text { Lactococcus lactis } \\
\text { Leuconstoc } \\
\text { mesenteroides } \\
\text { Pediococcus acidilactici } \\
\text { Sporolactobacillus } \\
\text { inulinus* } \\
\text { Streptococcus } \\
\text { thermophilus }\end{array}$ & $\begin{array}{l}\text { Bacillus cereus var. } \\
\text { toyoi* }^{*} \\
\text { Escherichia coli strain } \\
\text { Nissle } \\
\text { Propionibacterium } \\
\text { freudenreichii* } \\
\text { Saccharomyces } \\
\text { cerevisiae } \\
\text { Saccharomyces } \\
\text { boulardii }\end{array}$ \\
\hline
\end{tabular}

The word "probiotic" comes from Greek and means "for life" (Hamilton-Miller, 2004). Over the years, the term "probiotic" has been given several definitions. FAO/WHO (2002) stated that probiotics are "live microorganisms which when administered in adequate amounts confer a health benefit on the host". Recent document represented the conclusions of the International Scientific Association for Probiotics and Prebiotics (ISAPP) consensus meeting on the appropriate use and scope of the term probiotic (Hill et al., 2014).

S. boulardii (Figure 1) is a strain of yeast, first isolated from lychee fruit in Indochina and reported in the literature in 1920 by a French biologist Henri Boulard. Since 1980s, a series of studies on S. boulardii have been conducted to determine the benefits and mechanism of activity of this microorganism.

These studies utilized advanced analytical techniques, such as electrophoresis and PCR, to find the origin of $S$. boulardii (McFarland and Bernasconi, 1993; Mitterdorfer et al., 2002). Several taxonomic studies on $S$. boulardii have indicated that the yeast should be considered as a strain of Saccharomyces cerevisiae.

Also, S. boulardii is not recognized as a separate species according to current taxonomic keys and as such, the yeast should be referred to as Saccharomyces cerevisiae var. boulardii (van der Aa Kühle and Jespersen, 2003; Mc Farland et al., 2010).

In addition, the yeast $S$. boulardii can be separated from other strains of $S$. cerevisiae with respect to its probiotic potential and its inability to use the products of galactose and ascospores. For these reasons, some researchers believe that the probiotic yeast should be considered as its type.

Several studies specifically with micro satellite polymorphism showed a clear pattern on the basis of which it is possible to distinguish between $S$. boulardii and $S$. cerevisiae, there are also RAPD (Rapid Amplified Polymorphic DNA) and electrophoretic karyotypes analysis (Mc Farland et al., 2010).

Due to the conflicting research results in practice currently uses the name $S$. boulardii (nom. nud). The term is mainly used for species that are similar to known species, but not yet taxonomically classified.

These strains are in the process of obtaining scientific name, until a detailed description, which is in line with current standards nomenclature (ICZN, 2014).

$S$. boulardii has an unusually high optimal growth temperature of $37^{\circ} \mathrm{C}$. It is a unique probiotic, known to survive gastric acidity and it is not adversely affected or inhibited by antibiotics or does not alter or adversely affect the normal microbiota in the bowel (McFarland and Bernasconig, 1993; van der Aa Kühle et al., 2005). 


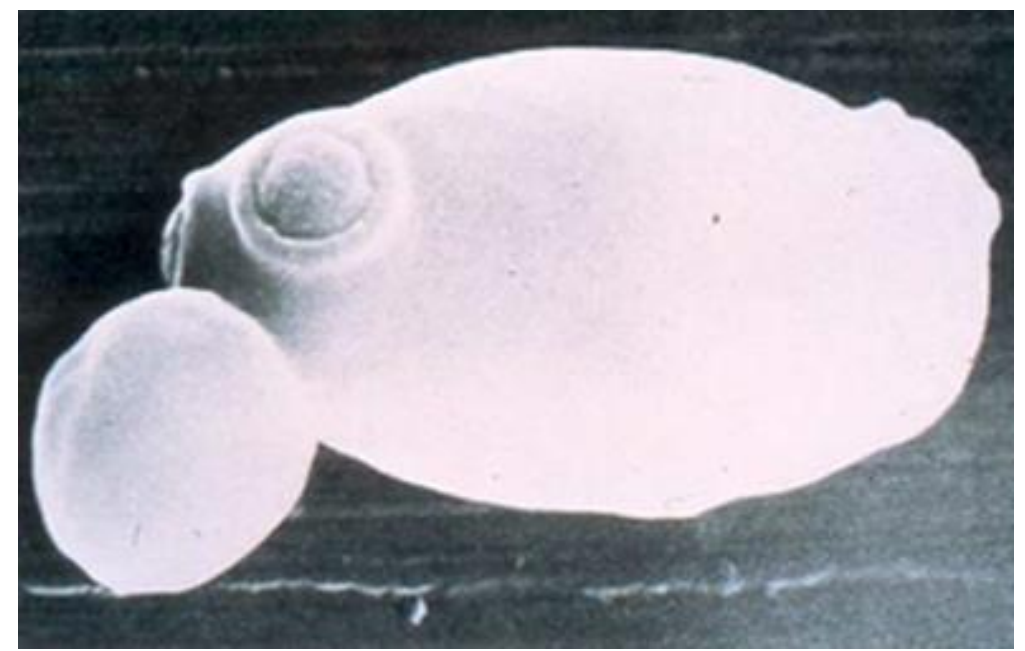

Figure 1. Scanning electron micrographs of S. boulardii (Czerucka et al., 2002)

It has been proven that $S$. boulardii has an antagonistic activity against various bacterial pathogens. It reduces the number of intracellular bacteria but does not modify the number of cell-associated bacteria (Czerucka et al., 2007).

S. boulardii has been utilized worldwide as a probiotic supplement to support gastrointestinal health. It benefits the gastrointestinal tract by increasing intestinal populations of healthy bifidobacteria and lactobacilli while decreasing numbers of disease-causing organisms.

Moreover, S. boulardii can reduce symptoms of inflamematory bowel disease, such as Crohn's colitis, where the clinical studies have indicated that $S$. boulardii cells were effective in the prevention and/or the treatment of Crohn's disease (Guslandi et al., 2003). This probiotic yeast also prevents or treat diarrheal diseases such as antibiotic-associated diarrhea (AAD), acute gastroenteritis, and chronic diarrhea in human immune-deficiency virus-infected patients (Guslandi et al., 2000; Pothoulakis, 2009).

\section{Efficacy of Saccharomyces boulardii as a probiotic}

S. boulardii has been used either to prevent or to treat human diseases by interacting with the natural microecology of the host. Beneficial effects of $S$. boulardii against enteric pathogens involve different mechanisms, such as competition with pathogens for nutrients; binding of cholera toxin to the $S$. boulardii cell wall, resulting in its elimination with yeast cells by peristalsis; inhibition of pathogen adhesion; degradation of bacterial toxins and their receptors on the host mucosa; stimulation of the enzymatic activity and intestinal mucosa immune response; and modulation of host cell signaling and proinflammatory gene expression (Billo et al., 2006; Kelesidis and Pothoulakis, 2012). Additionally, S. boulardii stimulates intestinal mucosa by secreting trophic factors and polyamines (Buts and de Keyser, 2006), contributing to the increase in host immune defense.

The reason for the significant pharmaceutical application of $S$. boulardii is that this is the only yeast species that has been proven via clinical trials to have probiotic activity. Many in vitro and some in vivo studies have suggested that $S$. boulardii is able to prevent intestinal infections caused by the adherence or invasion of Salmonella Typhimurium (Figure 2), Clostridium difficile, Escherichia coli, and Candida albicans to the epithelial layer of the gastrointestinal tract (Czerucka and Rampal., 2002; Tiago et al., 2012; Tomičić et al., 2016a).

Significantly, Qamar et al. (2001) demonstrated that $S$. boulardii is effective in helping the intestinal immune system to produce antibodies against the toxins pro- 
duced by pathogenic bacteria. According to the results, S. boulardii stimulates intestinal immunoglobulin A ( $\lg A)$, an antibody that plays an important role in the intestinal mucosal immunity (Czerucka et al., 2007; Qamar et al., 2001).

S. boulardii secretes enzymatic proteins, including a protease that degrades $C$. difficile toxins and a phosphatase that inactivates endotoxin such as the lipopolysaccharide produced by $E$. coli. S. boulardii also promotes production of disaccharidases such as lactase, sucrase, maltase, and $\mathrm{N}$-aminopeptidase in the brush border allowing increased carbohydrate degradation and absorption in patients with diarrhea, and restores normal levels of short chain fatty acids in the colon which are necessary for absorption of water and electrolytes (Marcia, 2009).

While there is quickly increasing information on the influence of $S$. boulardii on the bacterial origin diseases the interaction between S. boulardii and Candida spp. are much less studied.

However, recent in vitro studies have shown that the presence of $S$. boulardii cells can have a significant inhibitory effect on the adhesion of Candida spp., such as C. albicans and C. glabrata (Krasowska et

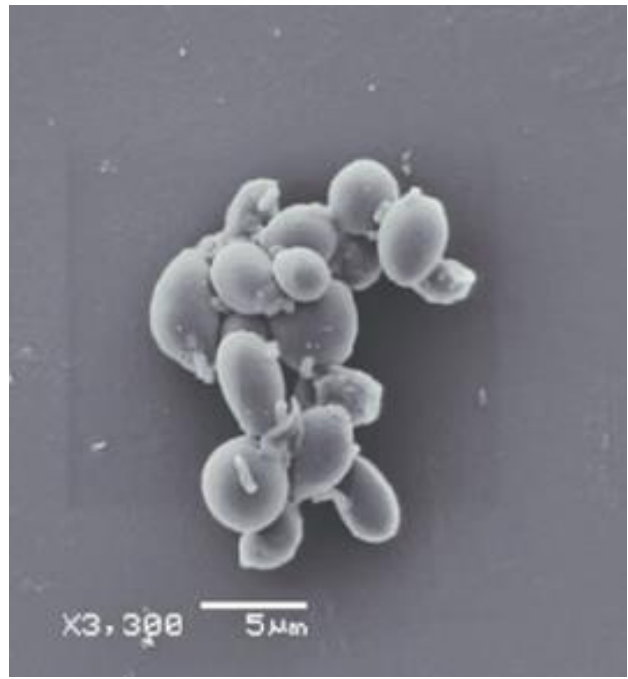

a) al., 2009; Tomičić et al., 2016b).

Further, $S$. boulardii is naturally resistant to antibiotics and therefore is not affected by antibiotics and sulfamide. It is considered as an effective means for the prevention and treatment of diarrhea, due to the imbalance of the intestinal microbiota in patients with long-term antibiotic treatment, whereas many other probiotics do not have this ability (Qamar et al., 2001).

Bacterial probiotics have considerable potential for preventive and therapeutic applications in AAD. However, it is important to note that the effects of any bacteria are strain specific and the efficacy demonstrated for a single given bacterial strain cannot be extrapolated to other probiotic organisms.

A variety of bacteria have been studied to explore their probiotic effect, Lactobacillus rhamnosus GG is a specific bacterial strain which demonstrates a probiotic effect in the prevention of AAD. Other strains of $L$. rhamnosus species may not have this effect, and likewise other species in the genus of Lactobacillus may not act as probiotics. This is because individual strains exhibit different specific characterristics, such as resistance to gastric acid and bile, ability to colonize the mucosa, and antimicrobial activity (Hickson, 2011).

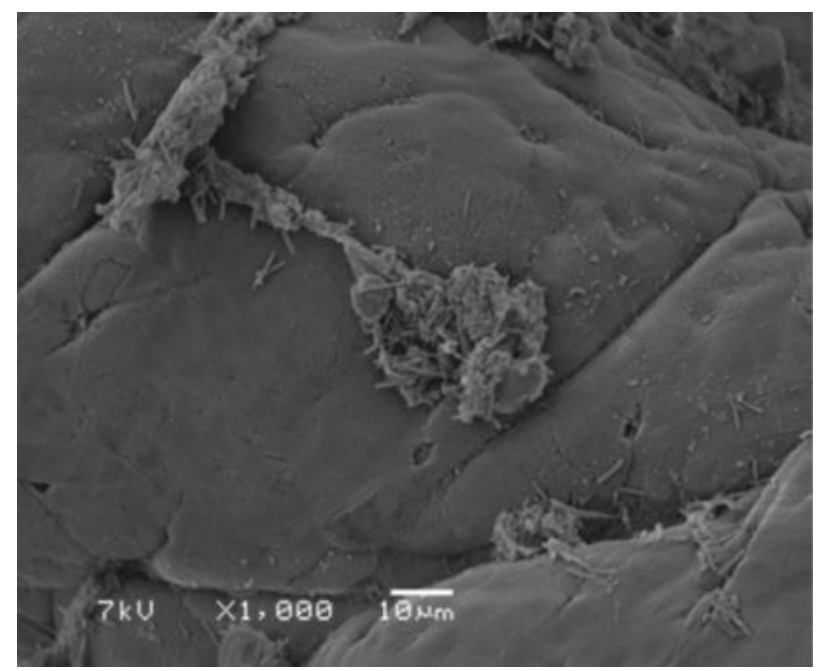

b)

Figure 2. Scanning electron micrograph of in vitro adhesion between Saccharomyces boulardii and Salmonella Typhimurium ATCC 14028 (a), Scanning electron micrograph of the intestinal epithelium of gnotobiotic mice associated with Saccharomyces boulardii plus Salmonella Typhimurium ATCC 14028

(b) (Tiago et al., 2012) 
Moreover, the mechanisms underlying probiotic action have not yet been fully elucidated. A better understanding of these mechanisms will be able to shed light on the disparate clinical data and provide new tools to help the prevention or treatment of health disorders (Wohlgemuth et al., 2010).

There are many different Saccharomyces products commercially available sold as probiotics and S. boulardii is usually available in capsules of either lyophilized or heat-dried preparations (McFarland et al., 2010).

The choice of a high-quality probiotic product is one of the most important factors that determine efficacy of the probiotic. The stability of the probiotic product may significantly affect its potency over time.

Lyophilized products are stable at room temperature, have the advantage of portability and maintain high viability counts over prolonged periods (Graff et al., 2008).

Heat-dried preparations must be refrigerated and may not be stable at room temperature (McFarland et al., 2010). On the other hand, the dose of $S$. boulardii used can also affect the efficacy of this probiotic (McFarland et al., 2010).

Probiotic organisms are increasingly incorporated into food as dietary adjuncts to help to maintain a healthy microbial gastrointestinal balance, with possible resulting benefits for the human health (Czerucka et al., 2007).

Application of $S$. boulardii as a food additive has been reported in the fermentation of vegetables (Sindhu and Khetarpaul, 2002) and incorporation into commercial yogurts (Lourens-Hattingh and Viljoen, 2001).

Potential application of $S$. boulardii in yoghurts could offer an alternative probiotic product to people suffering from antibioticassociated diarrhoea whilst on treatment (Beniwal et al., 2003; Karaolis et al., 2013).

Growth of a probiotic yeast, in association with the bio-yogurt microbiota, which is done by incorporating the yeast into commercial bio-yogurt, has been suggested as a way to stimulate growth of probiotic organisms and to assure their survival during storage (Lourens-Hattingh and $\mathrm{Vi}$ ljoen, 2001).

\section{Safety of Saccharomyces boulardii as a probiotic}

S. boulardii therapy has been used in thousands of patients in Europe for prevention and treatment of acute or chronic diarrhea.

Except for several sporadic reports of fungemia, in patients with severe general or intestinal disease who had an indwelling catheter (Cassone et al., 2003; Venugopalan et al., 2010; Whelan and Myers, 2010), S. boulardii is considered to be a safe and well-tolerated treatment. The origin of these cases of fungemia remains unclear, but is likely related to catheter colonization (Czerucka et al., 2007).

On the other hand, a recent systematic review documented that probiotic products such as $S$. boulardii, have been shown to increase the risk of complications in specific patient groups such as immunocompromised subjects (Whelan and Myers, 2010).

Therefore, the mechanisms of this yeast's probiotic action need to be identified, and any potential for virulence must be fully investigated.

\section{CONCLUSIONS}

In conclusion, using $S$. boulardii in the prevention and/or the treatment of diarrhea have been widely investigated and demonstrated.

However, new data and further experimental studies should permit to better elucidate the mechanisms of action of the yeast and suggest new therapeutic applications. Although the administration of $S$. boulardii can be associated with fungemia, no adverse effects were observed in any of the clinical trials.

Caution should be taken in patients with risk factors for adverse events, such as immunocompromised patients. 
Dairy foods can serve as the ideal system for delivery of probiotics to the human gastrointestinal tract (Andrade Araújo et al., 2012), due to provision of a favorable environment that promotes the growth and enhances the viability of these microorganisms.

\section{ACKNOWLEDGEMENTS}

This paper is a result of the research within the project "Application of novel and conventional processes for removal of most common contaminants, mycotoxins and salmonella, in order to produce safe animal feed in the territory of AP Vojvodina" financed by the Provincial secretariat for higher education and scientific research, Autonomous Province of Vojvodina, Republic of Serbia.

\section{REFERENCES}

1. Andrade Araújo, E., dos Santos Pires, A. C., Soares Pinto, M., Jan, G., de Carvalho, A. F. (2012). Probiotics in dairy fermented products. In Probiotics. Ed. E. Rigobelo, InTech, DOI: $10.5772 / 51939$

(http://www.intechopen.com/books/probiotics/pr obiotics-in-dairy-fermented-products).

2. Beniwal, R.S., Arena, V.C., Thomas, L., Narla, S., Imperiale, T.F., Chaudhry, R.A., Ahmad, U. A. (2003). A randomized trial of yogurt for prevention of antibiotic-associated diarrhea. Digestive Diseases and Sciences, 48, 20772082.

3. Billoo, A.G., Memon, M. A.,Khaskheli, S.A., Murtaza, G., Iqbal, K., Saeed Shekhani, M., Siddiqi, A.Q. (2006). Role of a probiotic (Saccharomyces boulardii ) in management and prevention of diarrhea. World Journal of Gastroenterology, 12, 4557-4560.

4. Buts, J.P., de Keyser, N. D. (2006). Effects of Saccharomyces boulardii on intestinal mucosa. Digestive Diseases and Sciences, 51, 14851492.

5. Cassone, M., Serra, P., Mondello, P., Girolamo, A., Scafetti, S., Pistella, E., Venditti, M. (2003). Outbreak of Saccharomyces cerevisiae subtype boulardii fungemia in patients neighboring those treated with a probiotic preparation of the organism. Journal of Clinical Microbiology, 41, 5340-5343.

6. Czerucka, D., Piche, T., Rampal, P. (2007). Review article: yeast as probiotics Saccharomyces boulardii. Alimentary Pharmacology \& Therapeutics, 26, 767-778.

7. Czerucka, D., Rampal, P. (2002). Experimental effects of Saccharomyces boulardii on diarrheal pathogens. Microbes and Infection, 4, 733-739.
8. FAO/WHO (2002). Working Group Report on Drafting Guidelines for the Evaluation of Probiotics in Food. London, ON, Canada, Food and Agriculture Organization/World Health Organization.

9. Graff, S., Chaumeil, J.C., Boy, P., Lai-Kuen, R., Charrueau, C. (2008). Formulations for protecting the probiotic Saccharomyces boulardii from degradation in acidic condition. Biological and Pharmaceutical Bulletin, 31 (2), 266-272.

10. Guslandi, M., Mezzi, G., Sorghi, M., Testoni, P. A. (2000). Saccharomyces boulardii in maintenance treatment of Crohn's disease. Digestive Diseases and Sciences, 45, 1462-1464.

11. Guslandi, M., Giollo, P., Testoni, P. A. (2003). A pilot trial of Saccharomyces boulardii in ulcerative colitis. European Journal of Gastroenterology and Hepatology, 15 (6), 697-698.

12. Hamilton-Miller, J.M.T. (2004). Probiotics and prebiotics in the elderly. Postgraduate Medical Journal, 80, 447-451.

13. Hickson, M. (2011). Probiotics in the prevention of antibiotic-associated diarrhoea and Clostridium difficile infection. Therapeutic Advances in Gastroenterology, 4 (3), 185-197.

14. Hill, C., Guarner, F., Reid., R, Gipson, G.R., Merenstein, D.J., Pot, B., Morelli, L., Canani, R. B., Flint, H.J., Salminen, S., Calder, P.C., Sanders, M.E. (2014). Expert consensus document. The International Scientific Association for Probiotics and Prebiotics consensus statement on the scope and appropriate use of the term probiotic. Nature Reviews Gastroenterology \& Hepatology, 11, 506-514.

15. Holzapfel, W.H., Haberer, P., Geisen, R., Björkroth, J., Schillinger, U. (2001). Taxonomy and important features of probiotic microorganisms in food and nutrition. The American Journal of Clinical Nutrition, 73, 365S-73S.

16. Karaolis, C., Botsaris, G., Pantelides, I., Tsaltas, D. (2013). Potential application of Saccharomyces boulardii as a probiotic in goat's yoghurt: survival and organoleptic effects. International Journal of Food Science and Technology, 48, 1445-1452.

17. Kelesidis, T., Pothoulakis, C. (2012). Efficacy and safety of the probiotic Saccharomyces boulardii for the prevention and therapy of gastrointestinal disorders. Therapeutic Advances in Gastroenterology, 5,111-25.

18. ICZN (2014). What is a nomen nudum. International Commission on Zoological Nomenclature, London, UK (http://iczn.org/content/what-nomen-nudum).

19. Krasowska, A., Murzyn, A., Dyjankiewicz, A., Łukaszewicz, M., Dziadkowiec, D. (2009). The antagonistic effect of Saccharomyces boulardii on Candida albicans filamentation, adhesion and biofilm formation. FEMS Yeast Research, 9, 1312-1321.

20. Lourens-Hattingh, A., Viljoen, B.C. (2001). Growth and survival of a probiotic yeast in dairy 
products. Food Research International, 34, 791-796.

21. Marcia, L.B. (2009). Saccharomyces boulardii as a probiotic for children. Pediatric Pharmacolotherapy, 15 (7), 1- 5.

22. McFarland, L.V., Bernasconi, P. (1993). Saccharomyces boulardii: A review of an innovative biotherapeutic agent. Microbial Ecology in Health and Disease, 6, 157-171.

23. McFarland, L. V. (2010). Systematic review and meta-analysis of Saccharomyces boulardii in adult patients. World Journal of Gastroenterology, 16 (18), 2202-2222.

24. Mitterdorfer, G., Mayer, H. K., Kneifel, W., Viernstein, H. (2002). Clustering of Saccharomyces boulardii strains within the species $S$. cerevisiae using molecular typing techniques. Journal of Applied Microbiology, 93, 521-530.

25. Pothoulakis, C. (2009). Review article: anti-inflammatory mechanisms of action of Saccharomyces boulardii. Alimentary Pharmacology \& Therapeutics, 30, 826-833.

26. Sindhu, S.C., Khetarpaul, N. (2002). Effect of probiotic fermentation on antinutrients and in vivo protein and starch digestibilities of indigenously developed RWGT food mixture. Nutrition and Health, 16, 173-181.

27. Tiago, F.C.P., Martins, F.S., Souza, E.L.S., Pimenta, P.F.P., Araujo, H.R.C., Castro, I.M., Brandao, R.L., Nicoli, J.R. (2012). Adhesion to the yeast cell surface as a mechanism for trapping pathogenic bacteria by Saccharomyces probiotics. Journal of Medical Microbiology, 61, 1194-1207.

28. Tomičić, R., Čabarkapa, I., Vukmirović, Đ., Lević, J., Tomičić, Z. (2016a). Influence of growth conditions on biofilm formation of Listeria monocitogenes. Food and Feed Research, 43 (1), 19-24.
29. Tomičić, Z., Zupan, J., Matos, T., Raspor, P. (2016b). Probiotic yeast Saccharomyces boulardii (nom. nud.) modulates adhesive properties of Candida glabrata. Medical Mycology, 54 (8), 835-845.

30. van der Aa Kühle, A.,Jespersen, L. (2003). The taxonomic position of Saccharomyces boulardii as evaluated by sequence analysis of the D1/D2 domain of 26S rDNA, the ITS1-5.8S rDNA-ITS2 region and the mitochondrial cytochrome-c oxidase II gene. Systematic and Applied Microbiology, 26 (4), 564-71.

31. van der Aa Kühle, A., Skovgaard, K., Jespersen, L. (2005). In vitro screening of probiotic properties of Saccharomyces cerevisiae var. boulardii and food-borne Saccharomyces cerevisiae strains. International Journal of Food Microbiology, 101, 29-39.

32. Venugopalan, V., Shriner, K.A., Wong-Beringer, A. (2010). Regulatory oversight and safety of probiotic use. Emerging Infectious Diseases, 16, 1661-1665.

33. Qamar, A., Aboudola, S., Warny, M., Michetti, P., Pothoulakis, C., LaMont, J.T., Kelly, C.P. (2001). Saccharomyces boulardii stimulates intestinal immunoglobulin A immune response to Clostridium difficile toxin A in mice. Infection and Immunity, 69 (4), 2762-2765.

34. Whelan, K., Myers, C.E. (2010). Safety of probiotics in patients receiving nutritional support: A systematic review of case reports, randomized controlled trials, and nonrandomized trials. The American Journal of Clinical Nutrition, 91, 687-703.

35. Wohlgemuth, S., Gunnar Loh, G., Blaut, M. (2010). Recent developments and perspectives in the investigation of probiotic effects. International Journal of Medical Microbiology, 300, 3-10. 


\title{
КОРИСНА СВОЈСТВА ПРОБИОТСКОГ КВАСЦА Saccharomyces boulardii
}

\author{
Зорица М. Томичић ${ }^{1 *}$, Радмило Р. Чоловић ${ }^{1}$, Ивана С. Чабаркапа ${ }^{1}$, Ђуро М. Вукмировић ${ }^{1}$, \\ Оливера М. Ђурагић ${ }^{1}$, Ружица М. Томичић ${ }^{2}$ \\ ${ }^{1}$ Научни институт за прехрамбене технологије у Новом Саду, Универзитет у Новом Саду, \\ 21000 Нови Сад, Булевар цара Лазара бр. 1, Србија \\ ${ }^{2}$ Технолошки фракултет, Универзитет у Новом Саду, 21000 Нови Сад, \\ Булевар цара Лазара бр. 1, Србија
}

Сажетак: Saccharomyces boulardii је једина врста квасца за коју је доказано да поседује својства која карактеришу пробиотике. S. boulardii је непатогени, термофилни квасац, који се користи у превенцији и лечењу цревних обољења, углавном дијареја. Ова врста се одликује способношћу проласка кроз гастроинтестинални тракт и делује инхибиторно на бројне патогене микроорганизме. Велики број клиничких студија потврђује његову ефикасност у лечењу акутних и хроничних гастроинтестиналних обољења. Његова потенцијална примена у разним млечним производима може да понуди алтернативни пробиотски производ за људе који пате од дијареје. Овај преглед разматра ефикасност и безбедност S. boulardii као пробиотика за превенцију и лечење гастроинтестиналних поремећаја код људи.

Кључне речи: Saccharomyces boulardii, ефикасност, безбедност, пробиотик

Received: 23 September 2016

Accepted: 5 December 2016 